"Production of bioethanol from carrot discards"

Authors: N.R. Aimaretti, C.V. Ybalo, M.L. Rojas, F.J. Plou, J.C. Yori

Published in:

Bioresource Technology, 123, 727-732 (2012)

doi:10.1016/j.biortech.2012.08.035 
1

2

3

\section{PRODUCTION OF BIOETHANOL FROM CARROT DISCARDS}

Nora R Aimaretti ${ }^{a, b^{*}}$, Carolina $V$ Ybalo ${ }^{b}$, María $L$ Rojas $^{c}$, Francisco J Plou $^{d}$, Juan C Yori $^{a}$

${ }^{a}$ Instituto de Investigaciones en Catálisis y Petroquímica. Facultad de Ingeniería Química. Universidad Nacional del Litoral (Santa Fe, Argentina).

${ }^{\text {b }}$ Laboratorio de Investigaciones Aplicadas. Facultad de Química. Universidad del Centro Educativo Latinoamericano (Rosario, Argentina).

Departamento de Química Inorgánica y Química Técnica. Facultad de Ciencias. Universidad Nacional de Educación a Distancia. (Madrid, Spain).

d Instituto de Catálisis y Petroleoquímica. Consejo Superior de Investigaciones Científicas. (Madrid, Spain).

* Corresponding author: Dra. Nora Aimaretti. Av Pellegrini 1332. 2000 Rosario

(Provincia de Santa Fe). Argentina. Tel/Fax: 0054341 4400540. E-mail: naimaretti@ucel.edu.ar, naimaretti@fbcb.unl.edu.ar 


\author{
ABSTRACT: \\ A revalorization of discarded carrots as substrate for the production of \\ second-generation ethanol is proposed. In order to increase the fermentable sugar \\ concentration of the musts two strategies were studied: Strategy 1 consisted in the \\ enzymatic hydrolysis of bagasse must and Strategy 2 by which carrots were milled, \\ dropped into distilled water and hydrolyzed with different enzymes prior to \\ compressing and filtering to obtain carrot must. By applying Strategy 2 using 0.05 \\ $\%(\mathrm{v} / \mathrm{v})$ of the enzyme Optimase $\mathrm{CX} 255$ at $70{ }^{\circ} \mathrm{C}$ and $\mathrm{pH} 5.5$ during $2.5 \mathrm{~h}$, the \\ fermentable sugars extracted increased 3.5 times. In this way, the production of \\ 77.5 $\mathrm{L}$ of ethanol for each ton of discarded carrots was achieved. This process \\ yielded bagasse as byproduct, which could be used for animal feed.
}

KEYWORDS: carrot, fermentation, ethanol, enzymatic hydrolysis

\title{
ABBREVIATIONS:
}

RS: reducing sugars

TS: total sugars

CM: carrot must

BM: bagasse must

DC: discarded carrot 


\section{INTRODUCTION}

At present, the dependence on fossil fuels is still strong (85-90 \%) in spite of their rapid depletion. In this context, the search for alternative energy sources has become a crucial issue that leads to the development of better technologies for second-generation biofuel production (Simsa et al., 2010).

The use of solar energy by means of the photosynthesis which produces biomass (Kreuger et al., 2011) is the most important source of renewable raw materials (Clark, 2005; Sánchez and Cardona, 2008). The acid or enzymatic hydrolysis of polysaccharides such as cellulose, hemicellulose, starch, inulin and chitosan in hexoses and pentoses allows their use in the alcoholic fermentative process. Of both types of hydrolysis, the enzymatic one allows obtaining a pure product with a low energy demand and a minor effluent production (Tomás, 2009; Ovando and Waliszewski, 2005) but the yield differs considerably depending on the applied technology (Sun and Cheng, 2002). In this way, bioethanol can be obtained from energy crops and lignocellulosic residues. The sustainability of the biotransformation processes must be analyzed from an economic and environmental point of view. Besides the high cost of current technologies and enzymes, another economic issue is to select cheap and abundant raw materials. That is why the use of regional agricultural and agro-industrial discards is very attractive to produce second-generation bioethanol (Laufenberg et al., 2003; Sánchez and Cardona, 2008; Aimaretti, 2011).

In Santa Fe (Argentina), a particular case is carrot (Daucus carota) cultivation whose average yield is nearly 40 tons $(\mathrm{t}) \mathrm{ha}^{-1}$ with a cultivated area of 
approximately 1,500 ha. During the harvest time, 20-100 t of carrots with an optimal degree of freshness and maturity are discarded daily due to a sizing problem and then directed to animal feed (Aimaretti, 2006). Carrot is one of the most efficient crops in biomass accumulation (Diamantopoulou et al., 2011) and it is one of the few plants that accumulate free sugars into vacuoles $(40-60 \%$ of total carbohydrates) as reserve carbohydrates. $95 \%$ of free sugars are composed of sucrose, fructose and glucose, and reducing sugars (RS) (fructose and glucose) are present in an equimolecular amount. The ratio sucrose/RS increases while the plant reaches maturity. After harvesting and during the cold storage, the ratio begins to fall down (Simon, 2000; Suojala, 2000).

Taking into account the above considerations, the present study had two main objectives: i) to evaluate the production of second-generation bioethanol using discarded carrots as raw material, and ii) to enhance the ethanol yield of the process by enzymatic hydrolysis in order to increase the fermentable sugar concentration of the must.

\section{MATERIALS AND METHODS}

\subsection{Raw material, handling and storage}

Discarded roots of carrot (DC) (Daucus carota) were collected in NovemberDecember 2010 from a packing shed in the Santa Fe area $\left(31^{\circ} 25^{\prime} \mathrm{S}, 60^{\circ} 20^{\prime} \mathrm{W}\right)$, Argentina. These discards were by-products from carrot packing processes, in which plant leaves were cut and whole roots were washed, dried and selected before packing. DC were stored in shed under ambient conditions $\left(20-32^{\circ} \mathrm{C} ; 50-60\right.$ 
$\%$ humidity). During delivery of random representative samples obtained by sampling methods (ANMAT, 2010), carrots were packed in a polypropylene container and moved to the laboratory where they were used immediately.

\subsection{Primary carrot processing}

For must preparation, DC were processed after discarding those rotten sections, to extract their juice by a continuous milling, compressing and filtering treatment. As a result of the treatment, two fractions were obtained: i) carrot juice, which was called carrot must $(\mathrm{CM})$ and ii) carrot bagasse which was utilized for the preparation of bagasse must (BM). The yield of the process was: $0.54 \mathrm{Kg} \mathrm{kg}^{-1}$ of $\mathrm{CM}$ and $0.46 \mathrm{~kg} \mathrm{~kg}^{-1}$ of bagasse. On the other hand, BM was prepared by dipping bagasse into a water volume in a proportion of $0.35 \mathrm{~kg} \mathrm{~L}^{-1}$.

\subsection{Enzymes}

The enzymes used in the hydrolysis reactions and the operational conditions performed are described in Table 1. The pretreatments were performed in a stirred tank reactor manufactured at UNL, Argentina, equipped with a controlled heating system. Agitation speed was regulated at $20 \mathrm{rpm}$ for all the experiments. Each enzyme has an indicated value of $\mathrm{pH}$ defined by its producers, which was adjusted with diluted sulfuric acid.

(Table 1, here)

\subsection{Enzymatic hydrolysis of Bagasse Must}

The seven commercial enzymes (Table 1) were evaluated under the conditions recommended by suppliers using BM as substrate. In each experiment, the enzyme dose was added after adjusting initial $\mathrm{pH}$ and temperature. The 
hydrolysis time was $2.5 \mathrm{~h}$ and homogeneous samples were taken every $30 \mathrm{~min}$. The samples were centrifuged during $10 \mathrm{~min}$ at 5,000 $\mathrm{xg}$ and the supernatants were used for determining the concentration of total sugars (TS) and reducing sugars (RS) by using the DNS method (see 2.8.2) and to analyze the carbohydrate composition (see 2.8.3) before the fermentation assay. All experiments were performed in duplicate and technical repeats were performed during each single experiment.

\subsection{Enzymatic hydrolysis of carrot prior to prepare carrot must}

Depending on the enzymatic activity and their availability, enzymes 1, 2, 4 and 5 (Table 1) were tested for enzymatic hydrolysis prior to preparing CM. In this way, DC was milled to a particle size minor to $4 \mathrm{~mm}$, dropped into distilled water and then enzymatically hydrolyzed. For these assays, batches containing $0.5 \mathrm{Kg}$ of milled DC dipped into water in a total volume of $1 \mathrm{~L}$ were mixed with the enzymes, after adjusting the initial $\mathrm{pH}$ and temperature. The hydrolysis was performed during $2.5 \mathrm{~h}$ and homogeneous samples were taken every $30 \mathrm{~min}$ of reaction. The samples were compressed and filtered to obtain $\mathrm{CM}$. The concentration of RS and TS was determined using the DNS method (see 2.8.2). All experiments were performed in duplicate and technical repeats were performed during each single experiment.

\subsection{Microorganism}

Saccharomyces cerevisiae CCUB filtered and discarded by a local brewing industry after five operative cycles, was utilized as biocatalyst in the fermentation reactions. Whole yeast cells were kept in a sterile container, without nutrient 
addition at $4{ }^{\circ} \mathrm{C}$ and saturation humidity during four days (Aimaretti and Ybalo, 2012). For the inoculum preparation, cells were suspended in an isotonic solution and counted by a differential direct count method in order to calculate the volume required (Alfenore et al., 2002).

\subsection{Fermentation conditions}

For alcoholic fermentations, fresh must was used in every case and its $\mathrm{pH}$ was adjusted to 4.5 . The inoculum was adjusted to a value of $10^{8}$ cell $\mathrm{mL}^{-1}$ (Aimaretti and Ybalo, 2012). Batch fermentations were developed to $28^{\circ} \mathrm{C}$, in a $500 \mathrm{~mL}$ stirred tank bio-reactor (self-manufactured), equipped with a controlled heating system. The agitation speed was regulated at $100 \mathrm{rpm}$ in all the experiments. A reactor hold-up of 0.25 was used, according to Laopaiboon et al. (2009). The alcoholic fermentation progress was monitored following $\mathrm{CO}_{2}$ production, which was collected in a gasometric probe (ANMAT, 2010). Samples at different reaction times were taken and submitted to centrifugation. Supernatants were transferred to Eppendorf tubes ( $1.5 \mathrm{~mL}$ of capacity) for their storage and conservation at $-20^{\circ} \mathrm{C}$. All experiments were performed in triplicate.

\subsection{Analytical methods}

\subsubsection{Moisture}

Moisture was determined using Approved Method 44-15A (AACC, 2005).

\subsubsection{Sugar concentration}

The concentration of reducing sugars was measured by the 3.5dinitrosalicylic acid (DNS) method (Aimaretti and Ybalo, 2012). The total sugar was 
assayed by the same method after acid hydrolysis $\left(1.2 \mathrm{~mol} \mathrm{~L}^{-1} \mathrm{HCl}\right.$, at $65^{\circ} \mathrm{C}$ for 15 min), neutralization with $1 \mathrm{~mol} \mathrm{~L}^{-1} \mathrm{NaOH}$ and filtration (Yu et al., 2009).

\subsubsection{Carbohydrate composition}

The analysis of carbohydrate composition in hydrolyzed musts was performed by high-performance anion exchange chromatography with pulsed amperometric detection HPAEC-PAD using an ICS-300 system (Dionex Corp, Sunnyvale, CA, USA) with a CarboPac ${ }^{\text {TM }}$ PA100 column $(4 \times 250 \mathrm{~mm}$, Dionex Corporation, CA, USA) with a guard column $(4 \times 50 \mathrm{~mm})$. The eluent and flow rate were $16 \mathrm{mM} \mathrm{NaOH}$ and $1 \mathrm{~mL} \mathrm{~min}^{-1}$ at $25^{\circ} \mathrm{C}$, respectively. Before the HPAEC-PAD analysis, the hydrolyzed samples were heated up to $85^{\circ} \mathrm{C}$ for 5 min in order to inactivate the enzymes; then, they were filtered and treated in a separate Sephadex G-25 column (Pharmacia, PD10) to remove high molecular weight molecules that can affect the HPLC column. $5 \mu \mathrm{L}$ of hydrolyzed sample together with $5 \mu \mathrm{L}$ internal standard (Lactulose, Anedra > $99.5 \%$ ) were injected in the chromatographer (Aimaretti, 2011). Measurements were made in duplicate.

\subsubsection{Ethanol concentration}

Ethanol concentration was determined by GC (PERKIN-ELMER, Sigma 3B, Dual FID Chromatograph, United States). A FID detector and a packed column of Chromosorb 102 (2.0m length) were employed. The column oven was operated isothermally at $150^{\circ} \mathrm{C}$ and the injection and detector ports were kept at $195^{\circ} \mathrm{C}$ and $220^{\circ} \mathrm{C}$, respectively. Nitrogen was used as carrier gas with a flow rate of $30 \mathrm{~mL}$ $\min ^{-1}$ and the combustion gas was a mixture of hydrogen and air. Isopropanol 
(Anedra, >99.9\%) was used as internal standard (Ratnam et al., 2003). In the chromatograph of every fermented sample, only two peaks appeared, one corresponding to the internal standard, and the other to ethanol.

\subsection{Fermentation parameters}

The following fermentation parameters were calculated to compare the responses of different assays:

$\mathrm{Y}_{\mathrm{p} / \mathrm{s}}$ : ethanol yield per substrate was considered as the ratio of total ethanol produced and the consumed sugars, $\left[\mathrm{g} \mathrm{g}^{-1}\right]$ (Colin and Bjorn, 2002). $\mathrm{Y}_{\mathrm{p} / \mathrm{c}}$ : ethanol yield per carrot was considered as the ratio of total ethanol produced and used carrot (dry base), [ $\mathrm{g} \mathrm{g}^{-1}$ ] (Colin and Bjorn, 2002).

Productivity: it was defined as total alcohol production over the total fermentation time, $\left[\mathrm{g} \mathrm{L}^{-1} \mathrm{~h}^{-1}\right]$ (Colin and Bjorn, 2002).

\section{RESULTS AND DISCUSSION}

\subsection{Carrot fermentation}

In the first experiment, two different musts were obtained from the primary processing of carrots ( $\mathrm{CM}$ and $\mathrm{BM})$ and the concentration of sugars was determined. They were fermented separately under conditions indicated in Section 2.7, comparing with un-inoculated $\mathrm{CM}$ and $\mathrm{BM}$.

The concentration of reducing sugars of CM was in average $49.8 \pm 13.4 \mathrm{~g}$ $\mathrm{L}^{-1}$, on a total of sugars $94.0 \pm 11.7 \mathrm{~g} \mathrm{~L}^{-1}$. After the CM fermentation, the ethanol concentration obtained was $37.1 \mathrm{~g} \mathrm{~L}^{-1}$. On the other hand, the average concentration of reducing sugars of BM was $5.8 \pm 0.4 \mathrm{~g} \mathrm{~L}^{-1}$, the concentration of 
total sugars: $29.6 \pm 4.7 \mathrm{~g} \mathrm{~L}^{-1}$, and the concentration of ethanol obtained by fermentation: $7.9 \mathrm{~g} \mathrm{~L}^{-1}$. Meanwhile, in the control experiments in which $\mathrm{CM}$ and $\mathrm{BM}$ were not inoculated, the ethanol concentration obtained was $0.0 \mathrm{~g} \mathrm{~L}^{-1}$. These results are indicative of the fact that ethanol is the main product of the metabolic way and its final yield depends on the sugar concentration, and they are in agreement with the results reported by Aimaretti and Ybalo (2012).

Taking into account that the humidity of $\mathrm{CM}$ was $85 \%$ and $60 \%$ for BM, then it can be observed that the fermentation allowed obtaining $Y_{p / c}$ values of 0.134 and $0.068 \mathrm{~g} \mathrm{~g}^{-1}$ after the of $\mathrm{CM}$ and $\mathrm{BM}$, respectively. So, the total $\mathrm{Y}_{\mathrm{p} / \mathrm{c}}$ of the primary carrot processing was $0.201 \mathrm{~g} \mathrm{~g}^{-1}$. In brief, $38.8 \mathrm{~L}$ of bioethanol were obtained from $1 \mathrm{t}$ of DC.

With the objective of increasing total sugar concentration of musts and the ethanol yield, two different enzymatic hydrolysis strategies were proposed for carrot processing.

\subsection{Strategy 1: Enzymatic hydrolysis of bagasse must (BM).}

The use of enzymes to hydrolyze the bagasse which resulted from the primary carrot processing could allow its use as a substrate for a fermentation process, thus increasing the overall productivity of DC (see 2.4).

Enzymes must be adsorbed on the particles surface of insoluble cellulose before the hydrolysis reaction begins. Thus, the three-dimensional structures of enzymes, in combination with their size and form, determine if the $\beta$-glycosidic bonds may be accessible to enzymatic attack or not (Tomás, 2009). Figure 1 shows the evolution of the reducing (Figure 1-A) and total sugars (Figure 1-B) as a function of 
hydrolysis time for the different enzymes. It can be observed that all the enzymes were capable of hydrolyzing the bagasse must increasing the sugar content in different proportions. In particular, the major improvements in total sugar content of must were 78.5 \% for enzyme Optimase CX255L and $75.5 \%$ for Enzigrex. It is also worth noting that the most active enzyme (OptimaseCX255L) is especially recommended by the supplier for reducing the viscosity of the components of the plant cell wall. The enzymatic hydrolysis of bagasse was also proposed as an interesting way for re-evaluating the large bagasse surplus from the juice industry (Yoon et al., 2005).

On the other hand, a noticeable effect was observed: an important increase of the reducing sugars catalyzed by Fungamyl (enzyme 7). This result is contradictory because, according to the supplier Fugamyl only presents $\alpha$-amylase activity (Table 1 ) and only $1 \%$ of the bagasse fiber is composed of starch. This could be explained by the fact that Fungamyl presents some invertase or alphaglucosidase residual activity to hydrolyze sucrose (Yoon et al., 2005).

(Figure 1, here)

\subsubsection{Carbohydrate composition of hydrolyzed bagasse musts}

The analysis of the hydrolyzed BM carbohydrate composition was carried out in order to determine the extension of the hydrolysis reaction with each enzyme. From the analysis many issues can be raised:

(i) during the filtering step of samples on Sephadex G-25 column, no high molecular weight polymers were found, which would indicate the absence of intermediate hydrolysis compounds. 
(ii) during the cromatography analysis both the not-hydrolyzed BM sample and all the hydrolyzed samples presented only three peaks, corresponding to glucose, fructose and sucrose. It represents one of the advantages of the method, since all these sugars are capable of being fermented (Sun and Cheng, 2002).

The absence of degradation compounds such as xylose and/or arabinose indicated that hydrolysis process was not effective to degrade cellulose and hemicellulose. Probably the enzymatic degradation of cellulose and hemicellulose into simple sugars requires longer reaction times (Sánchez and Cardona, 2008). Therefore, the increase of TS in the hydrolyzed musts might be related with the release of the free sugars accumulated in the carrot vacuoles. Enzymatic hydrolysis was an effective way to cause destabilization of the cell wall structure of the storage vacuoles allowing the release of free sugars.

The sugar profiles of hydrolyzed and control BM samples showed that for all hydrolyzed samples, the glucose content was higher than that of fructose whereas in the control BM samples their concentrations were equimolecular. This is indicative that the process produced a partial hydrolysis of some polysaccharides mainly composed of glucose. The result obtained with enzyme 7 in which sucrose and starch were totally degraded into glucose units must be highlighted.

\subsubsection{Fermentation of the hydrolyzed bagasse musts}

The above results are not enough to conclude about the benefit that the increase of sugars can exercise on ethanol yields. For this reason, the hydrolyzed musts were fermented. The ethanol obtained and its $Y_{p / s}$ values are shown in Table 2 for the seven enzymes at maximum hydrolysis times. In cases in which the 
increase was slow (enzyme 4 and 7) or too fast (enzyme 6) musts with different hydrolysis time were fermented. The analysis of the results shows that the higher the concentration of sugars in the hydrolyzed must the higher the ethanol yield obtained, as expected. This fact rules out the possibility that among the hydrolysis products there are substances that could inhibit the biocatalyst or that are nonfermentable sugars, like it was mentioned by Sun and Cheng (2002). (Table 2 here)

Summarizing, Figure 2 showed that it is interesting to note that the enzymatic hydrolysis of BM with enzymes Enzigrex or OptimaseCX255, during $2 \mathrm{~h}$ and $2.5 \mathrm{~h}$, respectively, at their optimal conditions (Table1), allowed triplicating the ethanol obtained $\left(Y_{p / c}=0.133 \mathrm{~g} \cdot \mathrm{g}^{-1}\right)$. Therefore, taking into account the ethanol yield with $\mathrm{CM}$ (see 3.1.), the total $\mathrm{Y}_{\mathrm{p} / \mathrm{c}}$ reached by Strategy 1 in these conditions was $0.267 \mathrm{~g} \mathrm{~g}^{-1}$. Comparing this value with the one corresponding to primary carrot processing, the increase of ethanol yield is $100 \%$ and $51.3 \mathrm{~L}$ of bioethanol might be obtained from each ton of DC.

(Figure 2, here)

\subsection{Strategy 2: Enzymatic hydrolysis previous to CM preparation}

The scientific community has spent much effort in studying the application of enzymes in the vegetal juice industry in the past two decades, because it has proven to be a versatile tool for releasing components of tissue cells and intracellular compounds, thus improving juice productivity (Ovando and Waliszewski, 2005). In this way, enzymatic hydrolysis of DC previous to CM preparation was studied as a strategy to increase the extracted sugar and 
consequently the ethanol yield. Enzymes 1, 2, 4 and 5 were used according to the supplier`s specifications and their availability.

Results showed that as time elapsed all enzymes increased the extracted volume of juice compared with the original $\mathrm{CM}$. In spite of this, the juice volume extracted at different time of hydrolysis, its sugar concentration and the kinetics were different for each enzyme reaching an increase of about $50-60 \%$ in some cases. Though the majority of the enzymes reached the maximum juice extraction at $2.5 \mathrm{~h}$, enzyme 5 allowed obtaining such volume increase in only $1 \mathrm{~h}$. In order to evaluate the efficiency of the different enzymes, the total sugar extracted after 2.5 $\mathrm{h}$ of hydrolysis expressed as $\left(\mathrm{g} \mathrm{kg}^{-1}\right.$ carrot) is indicated in Table 3 together with the sugar concentrations of the must ( $\mathrm{g} \mathrm{L}^{-1}$ must) used for fermentation. These results show that the higher yield in sugars extraction is obtained with the OptimaseCX255L biocatalyst during $1 \mathrm{~h}$ at enzyme optimal conditions. In this case, comparing with $\mathrm{CM}$ without enzyme treatment (see 3.1.), the extracted sugar was increased 3.5 times.

As in previous experiments, the analysis of carbohydrate composition of each hydrolyzed must showed that the sugars present were sucrose, fructose and glucose, all of them capable of being used by the yeast through alcoholic fermentation.

\subsubsection{Fermentation of $\mathrm{CM}$}

The results of the fermentation of the CM obtained by different enzymatic hydrolysis are shown in Table 3 in comparison with those corresponding to original CM. In agreement with previous results (see 3.2.2), it can be observed that by 
increasing the concentration of total sugars in the musts, the $\mathrm{Yp} / \mathrm{s}$ values remain almost constant meaning that all substrates would be fermentable, but instead, $Y_{p / c}$ values vary substantially due to the different sugar extraction during must preparation. In fact, the $Y_{p / c}$ could be increased 3 times if DC was hydrolyzed with enzyme 5 before extracting the juice.

(Table 3 here)

In this way, Strategy 2 using enzyme OptimaseCX255 at its optimal conditions (see Table 1) during $1 \mathrm{~h}$ reached an $Y_{p / c}=0.403 \mathrm{~g} \mathrm{~g}^{-1}$, as shown in Figure 2. So it allowed us to obtain $77.5 \mathrm{~L}$ of second-generation bioethanol from $1 \mathrm{t}$ of DC turning itself into an interesting alternative which allows increasing the ethanol yield of discarded carrots. Thus, the remaining bagasse may be used for animal feed, as suggested by Castillo and Gallardo (1989).

It can be observed that though the ethanol yield of each ton of carrot may be minor to the one obtained with traditional crops, the high yield of biomass per each ha of carrot cultivation in this area gives an ethanol yield of $3,100 \mathrm{~L} \mathrm{ha}^{-1}$, similar to the yields of corn and sorghum, 2,960 $\mathrm{L} \mathrm{ha}^{-1}$ and 3,010 $\mathrm{L} \mathrm{ha}^{-1}$, respectively (Sánchez and Cardona, 2008).

\section{CONCLUSIONS}

Enzymatic hydrolysis was adjusted to increase the ethanol yield and improve discarded carrot valorization. The two Strategies were efficient but enzymatic hydrolysis prior to CM preparation (Strategy 2) allowed duplicating the ethanol yield with respect to the must prepared without hydrolysis. Considering the 
daily average of discarded amount, 4,650 L day ${ }^{-1}$ of second-generation bioethanol could be produced in this area. It is important to continue the global analysis of the process since after the distillation of the ethanol, a vinasse rich in water arises that might be used for animal feed as the fiber-rich bagasse remaining from the preparation of $\mathrm{CM}$.

\section{ACKNOWLEDGEMENTS}

The authors wish to thank Agustín Codevilla and Mercedes Escorcia for their valuable cooperation. Thanks are also given to Agencia Santafesina de Seguridad Alimentaria for the use of their equipment. This work was performed with the financial support of the Latin American Educational Centre University (UCEL), Project ALI 121 grant and Project BIO2010-20508-C04-01 from the Spanish Ministry of Science and Innovation supported this research.

\section{REFERENCES}

AACC International Approved methods of analysis, 2005. Method 44-15.02. Moisture e Air-Oven methods. 12th ed. St. Paul, MN, U.S.A: American Association of Cereal Chemists (AACC) International.

Aimaretti, N., Ybalo, C., 2012. Valorization of carrot and yeast discards for the obtention of ethanol. Biomass and Bioenerg. 42, 18-23.

Aimaretti, N., 2011. Desarrollo de un Proceso Sostenible para la Producción de Bioetanol a partir de Desechos Agroindustriales. Dr. Thesis. Facultad de 
Ciencias. Universidad Nacional de Educación a Distancia. Madrid. España. 2011.

Aimaretti, N., 2006. Aprovechamiento de Residuos Agroindustriales para la Obtención de Nuevos Productos Alimenticios. M.Sc. Thesis. Facultad de Ingeniería Química. Universidad Nacional del Litoral. Santa Fe. Argentina.

ANMAT: Administración Nacional de Medicamentos, Alimentos y Tecnología Médica, 2010. Código Alimentario Argentino.. (www.anmat.gov.ar/codigoa).

Alfenore, S., Molina-Jouve, C., Guillouet, S.E., Uribelarrea, J.L., Goma, G., Benbadis, L., 2002. Improving ethanol production and viability of Saccharomyces cerevisiae by a vitamin feeding strategy during fed-batch process. Appl Microbiol Biotechnol. 60, 67-72.

Castillo, A., Gallardo, M., 1989. Alimentos no tradicionales en ganado lechero. Consideraciones prácticas para su utilización. E.E.A INTA Rafaela. Información para extensión. 88, 25-32.

Clark, J., 2005. Green chemistry for the second generation biorefinery- sustainable chemical manufacturing based on biomass. J Chem Technol Biotechnol. 82(7), 603-609.

Colin, R., Bjorn, K., 2002. Basic Biotechnology 2nd ed. Cambridge: Cambridge University Press.

Diamantopoulou, L.K., Karaoglanoglou, L.S., Koukios, E.G., 2011. Biomass Cost Index: Mapping biomass-to-biohydrogen feedstock costs by a new approach. Bioresour Technol. 102 (3), 2641-2650. 
Kreuger, E., Sipos, B., Zacchi, G., Svensson, S., Björnsson, L., 2011. Bioconversion of industrial hemp to ethanol and methane: The benefits of steam pretreatment and co-production. Bioresour Technol. 102 (20), 95249531.

Laopaiboon, L., Nuanpeng, S., Srinophakun, P., Klanrit, P. Laopaiboon, P., 2009. Ethanol production from sweet sorghum juice using very high gravity technology: Effects of carbon and nitrogen supplementations. Bioresour Technol. 100 (18), 4176-4182.

Laufenberg, G., Kunz, B., Nystroem, M., 2003. Transformation of vegetable waste into value added products: (A) the upgrading concept; (B) practical implementations. Review. Bioresour Technol. 87, 167-198.

Ovando, S., Waliszewski, K., 2005. Preparativos de celulasas comerciales y aplicaciones en procesos extractivos. Universidad y Ciencia. 21(42), 113122.

Ratnam, B., Narasimha Rao, M., Damodara Rao, M., Subba Rao, S., Ayyanna, C., 2003. Optimization of fermentation conditions for the production of ethanol from sago starch using response methodology. World J Microb Biot. 19, 523-6.

Sánchez, O., Cardona, C., 2008. Trends in biotechnological production of fuel ethanol from different feedstocks. Bioresour Technol. 99(13), 5270-5295.

Simon, P., 2000. Domestication, historical development, and modern breeding of carrot. Plant Breeding, 19, 157-190. 
Simsa, R., Mabeeb, W., Saddlerc, J., Taylord, M., 2010. An overview of second generation biofuel technologies. Bioresour Technol. 101(6),1570-1580.

Suojala, T., 2000. Variation in sugar content and composition of carrot storage roots at harvest and during storage. Sci Hortic Amsterdam. 85, 1-19.

Sun, Y., Cheng, J., 2002. Hydrolysis of lignocellulosic materials for ethanol production: a review. Bioresour Technol. 83(1), 1-11.

Tomás, M., 2009. Bioetanol de paja de trigo: estrategias de integración de las etapas del proceso. Dr Thesis. Facultad de Ciencias Biológicas. Universidad Complutense de Madrid. España

Yoon, K., Cha, M., Shin, S., Kim, K., 2005. Enzymatic production of a soluble-fibre hydrolyzate from carrot pomace and its sugar composition. Food Chem. 92, 151-157.

Yu, J., Zhang, X., Tan, T., 2009. Optimization of media conditions for the production of ethanol from sweet sorghum juice by immobilized Saccharomyces cerevisiae. Biomass and Bioenerg. 33, 521-526. 


\section{FIGURE CAPTIONS}

Figure 1: Reducing sugar (top graph) and total sugars (low graph) in BM during different enzymatic hydrolysis. (Ref.: 1: Rohament CL; 2: Rohalase OS; 3:

Enzigrex; 4: IndiAge MAX L; 5: Optimase CX255L; 6: Spirizyme Fuel; 7: Fungamyl).

Figure 2: Schemes of the two different strategies proposed.

\section{TABLE CAPTIONS}

Table 1: Enzymes' specifications.

Table 2: Total sugars and ethanol obtained in hydrolyzed BM.

Table 3: Total sugars extracted from carrot and fermentation parameters of fermentation of CM previously hydrolyzed. 


\section{FIGURE 1}

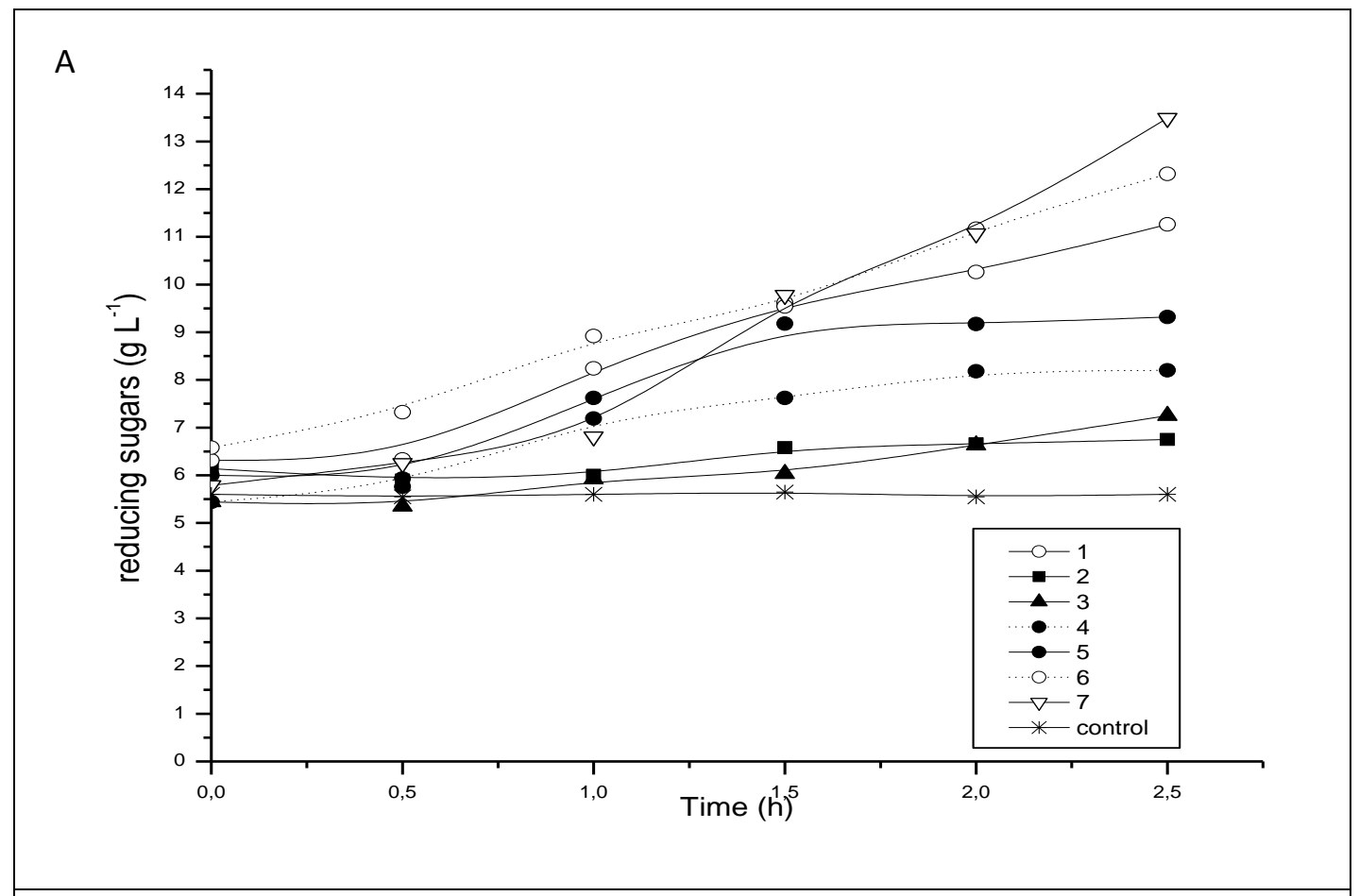

B

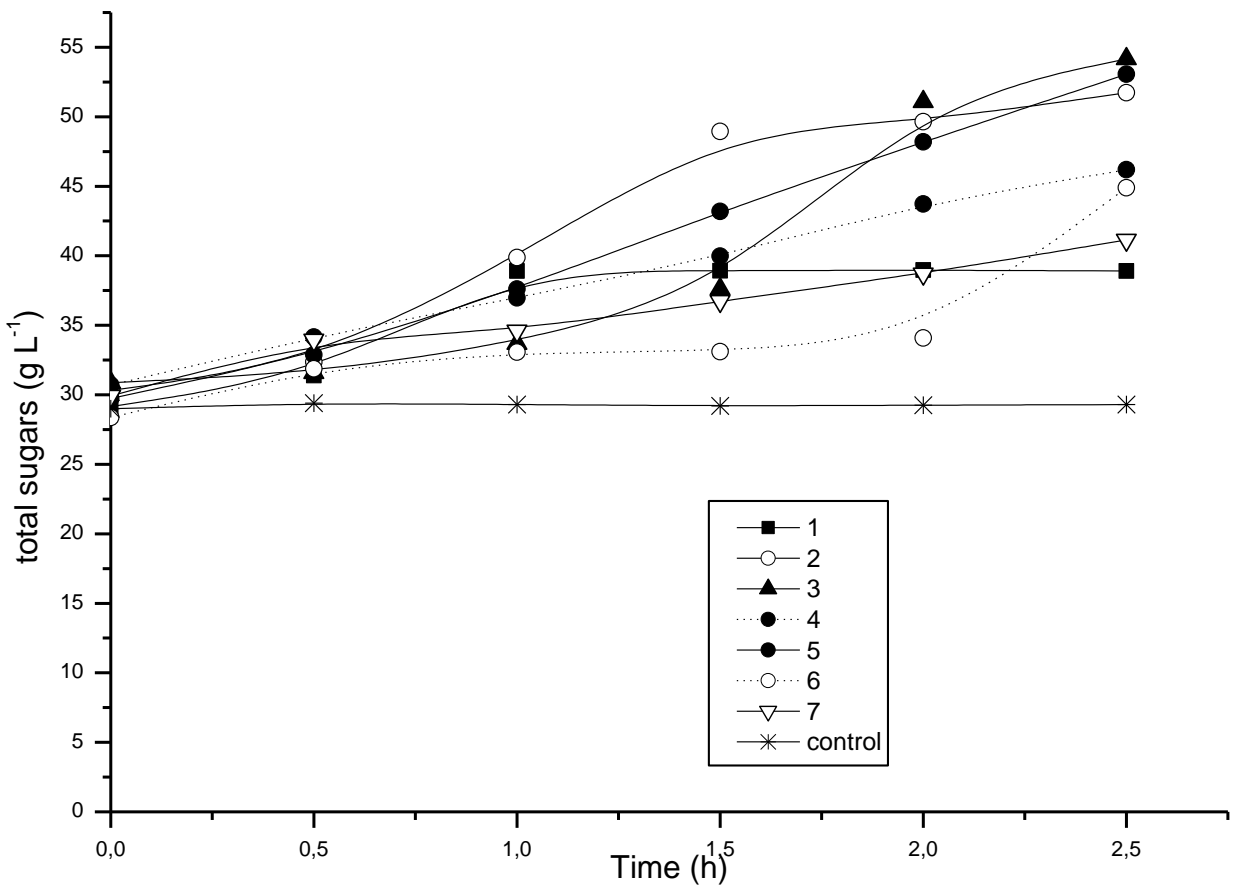




\section{FIGURE 2}

TWO STRAGIES TO INCREASE ETHANOL YIELD FORM DISCARDED CARROTS

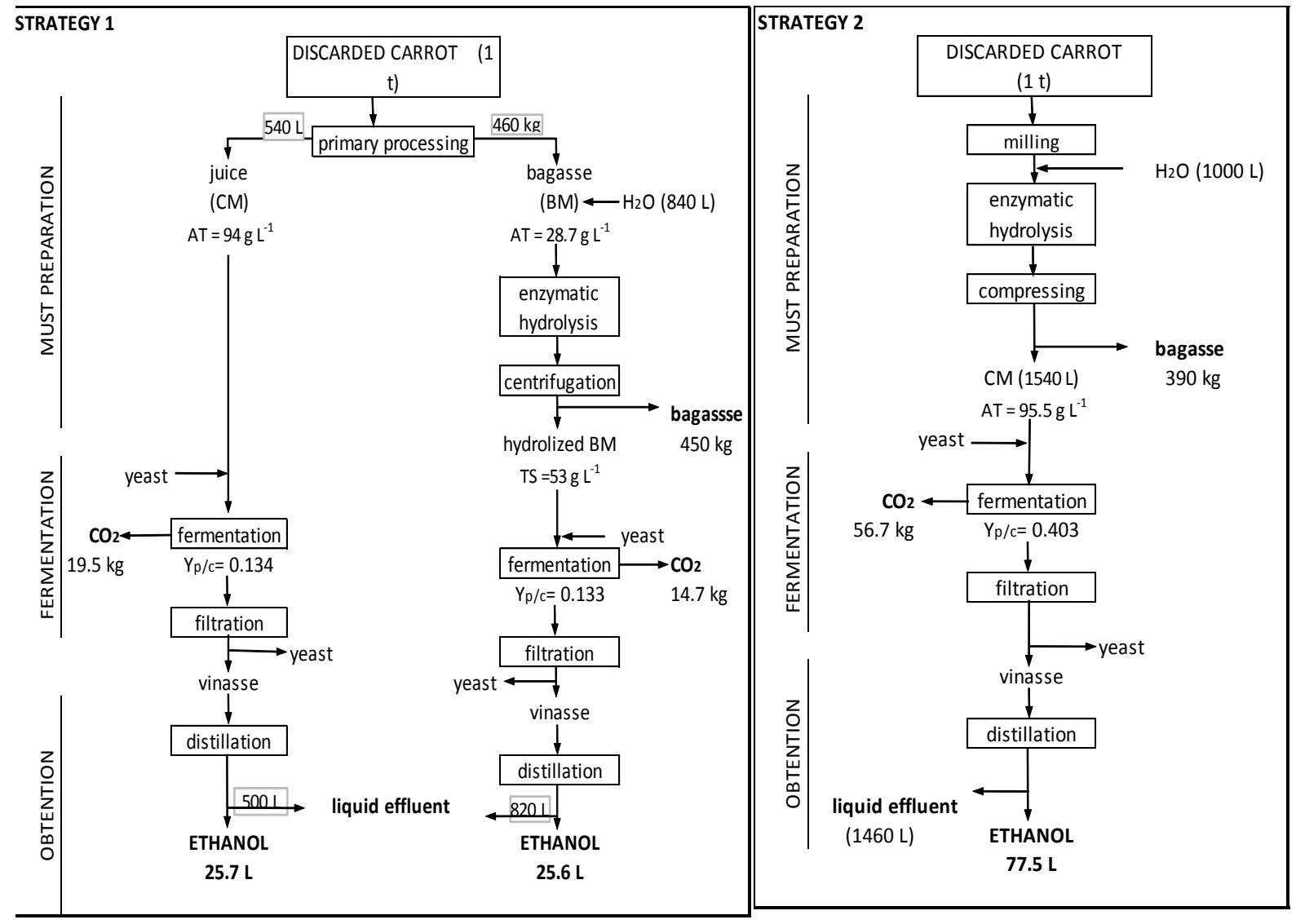




\section{TABLE 1}

\begin{tabular}{ccccccc}
\hline Ref. & $\begin{array}{c}\text { commercial } \\
\text { name }\end{array}$ & $\begin{array}{c}\text { enzymatic } \\
\text { activity }\end{array}$ & Origin & Temp. & $\mathrm{pH}$ & Doses \\
\hline 1 & Rohament CL & $\begin{array}{c}\text { endo-1,4- } \beta \text { - } \\
\text { glucanase }\end{array}$ & $\begin{array}{c}\text { Trichoderma } \\
\text { reesei }\end{array}$ & $50{ }^{\circ} \mathrm{C}$ & 5.0 & $0.05 \% \mathrm{v} / \mathrm{v}$ \\
\hline 2 & Rohalase OS & $\begin{array}{c}\text { cellulase } \\
\text { betaglucanase } \\
\text { xylanase }\end{array}$ & $\begin{array}{c}\text { Trichoderma } \\
\text { reesei }\end{array}$ & $55^{\circ} \mathrm{C}$ & 5.5 & $0.05 \% \mathrm{v} / \mathrm{v}$ \\
\hline 3 & Enzigrex & $\begin{array}{c}\text { experimental } \\
\text { cellulase }\end{array}$ & $\begin{array}{c}\text { Trichoderma } \\
\text { reesei }\end{array}$ & $50^{\circ} \mathrm{C}$ & 5.5 & $0.02 \% \mathrm{w} / \mathrm{v}$ \\
\hline 4 & IndiAge MAX L & Cellulase & $\begin{array}{c}\text { Trichoderma } \\
\text { reesei }\end{array}$ & $50^{\circ} \mathrm{C}$ & 5.0 & $0.05 \% \mathrm{v} / \mathrm{v}$ \\
\hline 5 & OptimaseCX255L & $\begin{array}{c}\text { Thermostable } \\
\text { Xylanase }\end{array}$ & $\begin{array}{c}\text { Trichoderma } \\
\text { reesei }\end{array}$ & $70^{\circ} \mathrm{C}$ & 5.5 & $0.05 \% \mathrm{v} / \mathrm{v}$ \\
\hline 6 & Spirizyme Fuel & Amyloglucosidase & $\begin{array}{c}\text { Aspergillus } \\
\text { niger }\end{array}$ & $65^{\circ} \mathrm{C}$ & 4.5 & $0.25 \% \mathrm{v} / \mathrm{v}$ \\
\hline 7 & Fungamyl & a-amylase & $\begin{array}{c}\text { Aspergillus } \\
\text { oryzae }\end{array}$ & $55^{\circ} \mathrm{C}$ & 4.7 & $0.32 \% \mathrm{w} / \mathrm{v}$ \\
\hline
\end{tabular}


TABLE 2

\begin{tabular}{|c|c|c|c|c|}
\hline ENZYME $^{a}$ & $\begin{array}{l}\text { Incubation } \\
\text { Time (h) }\end{array}$ & $\begin{array}{c}\text { Total sugars } \\
\left(\mathrm{g} \mathrm{L}^{-1}\right)\end{array}$ & $\begin{array}{l}\text { Ethanol } \\
\left(\mathrm{g} \mathrm{L}^{-1}\right)\end{array}$ & $\begin{array}{l}Y_{p / s} \\
\left(g^{-1}\right)\end{array}$ \\
\hline - & - & $28.7 \pm 0.1$ & $5.9 \pm 0.2$ & 0.205 \\
\hline 1 & 1.5 & $48.9 \pm 0.4$ & $11.5 \pm 0.5$ & 0.235 \\
\hline 2 & 1.5 & $38.6 \pm 0.3$ & $8.9 \pm 0.4$ & 0.230 \\
\hline 3 & 2.0 & $51.1 \pm 0.4$ & $15.4 \pm 0.5$ & 0.301 \\
\hline 4 & 2.0 & $43.7 \pm 0.2$ & $8.9 \pm 0.4$ & 0.204 \\
\hline 4 & 2.5 & $46.2 \pm 0.4$ & $10.0 \pm 0.3$ & 0.216 \\
\hline 5 & 2.5 & $53.1 \pm 0.3$ & $15.4 \pm 0.2$ & 0.290 \\
\hline 6 & 2.0 & $34.1 \pm 0.3$ & $8.2 \pm 0.2$ & 0.241 \\
\hline 6 & 2.5 & $44.9 \pm 0.2$ & $11.1 \pm 0.3$ & 0.247 \\
\hline 7 & 2.0 & $34.7 \pm 0.1$ & $7.1 \pm 0.2$ & 0.205 \\
\hline 7 & 2.5 & $41.1 \pm 0.4$ & $9.0 \pm 0.2$ & 0.219 \\
\hline
\end{tabular}

${ }^{\mathrm{a}}$ Table 2 


\section{TABLE 3}

\begin{tabular}{cccccc}
\hline ENZYME $^{\mathrm{a}}$ & $\begin{array}{c}\mathrm{TS} \\
\left(\mathrm{g} \mathrm{kg}_{\text {carrot }}\right)\end{array}$ & $\begin{array}{c}\mathrm{TS} \\
\left(\mathrm{g} \mathrm{L}_{\text {must }}\right)\end{array}$ & $\begin{array}{c}\text { Ethanol } \\
\left(\mathrm{g} \mathrm{L}^{-1}\right)\end{array}$ & $\begin{array}{c}\mathrm{Y}_{\mathrm{p} / \mathrm{s}} \\
\left(\mathrm{g} \mathrm{g}^{-1}\right)\end{array}$ & $\begin{array}{c}\mathrm{Y}_{\mathrm{p} / \mathrm{c}} \\
\left(\mathrm{g} \mathrm{g}^{-1}\right)\end{array}$ \\
\hline- & $42.3 \pm 0.3$ & $94.3 \pm 0.7$ & $37.1 \pm 0.3$ & 0.393 & 0.133 \\
1 & $126.9 \pm 0.7$ & $84.6 \pm 0.6$ & $29.0 \pm 0.5$ & 0.343 & 0.290 \\
2 & $106.5 \pm 0.6$ & $71.0 \pm 0.3$ & $27.3 \pm 0.5$ & 0.385 & 0.273 \\
4 & $102.4 \pm 0.6$ & $68.2 \pm 0.3$ & $27.9 \pm 0.5$ & 0.409 & 0.279 \\
5 & $150.2 \pm 0.6$ & $95.6 \pm 0.6$ & $40.3 \pm 0.6$ & 0.422 & 0.403 \\
\hline
\end{tabular}

\footnotetext{
${ }^{a}$ Table 3
} 